\title{
SIMPLE PRESENT TENSE VERB AND ADJECTIVES IN DESCRIPTIVE TEXT
}

\author{
Nurul Hikmah ${ }^{1}$, \\ Supeno ${ }^{2}$, \\ Postgraduate Faculty, Universitas Indraprasta PGRI, Jakarta \\ e-mail: nurulhikmah20@ gmail.com ${ }^{1}$ \\ e-mail: supeno@unindra.ac.id ${ }^{2}$
}

\begin{abstract}
This objectives study are 1) to analyze and to know whether or not there are errors of simple present verb in students writing descriptive text; 2) to analyze and to know if there are errors of adjectives in students writing descriptive text; 3) to know the cause of errors simple present tense verb and adjectives in students writing descriptive text. The tenth-grade students at Islamic Centre high school and Nusantara 1 high school in Tangerang in the academic year 2019/2020 are the participants in this current research. The research is a case study and used a descriptive approach. The instrument of this study is the writing test. There were 30 writing had been analyzed. The results show the error of simple present verbs for errors omission $(65,26 \%)$, addition $(5,26 \%)$, selection $(28,42 \%)$, misordering $(1,05 \%)$. And errors in using adjective percentage: omission $(13,95 \%)$, addition $(0 \%)$, selection $(76,34 \%)$, misordering $(9,30 \%)$. The reasons for errors in simple present tense and adjectives in writing descriptive text made by students are interlingual and intralingual errors.
\end{abstract}

Keywords: error analysis; simple present tense verb; adjective; descriptive text.

\section{Introductions}

In Indonesia, English is a foreign language taught in elementary school until university level. The English language taught in school and university helps the students learn English as the main subject in the following school level. In elementary school, students are introduced to English vocabulary and comprehend English text. Then, in senior high school, students still learn both of them, but in more profound ability, composing texts as one of English skills term in writing.

There are many differences between Indonesian and English systems; one of them is a structural system. The structural system is the arrangement of and relations between the parts or elements of something complex. Something complex here is the structure in writing, especially in writing descriptive text. In writing, the students should understand the grammatical of sentences.

English grammatical competence is different from Indonesian. Indonesian verb "memiliki" could be used interchangeably in written. It was caused by the Indonesian students who faced difficulties and made some errors in writing sentences. They often encountered difficulties in translating Indonesian sentences into English. For example, "My mother have short hair," instead of writing "My mother has short hair." They also write, "She have hobby cooking and go holiday," the correct one should be "She has hobbies in cooking and goes on holiday."

In learning English as a non-mother tongue language, most students think learning English is a problem. Students do not translate their sentences into English sentences by using grammar rules. They lack motivation, vocabulary items, seldom practice, negative attitude toward English, being introvert, and always translating their Indonesian sentence, not using grammar rules, especially in writing sentences. Furthermore, they cannot speak English fluently and are often confused about using appropriate tenses when writing sentences or analyzing what words are used in the paragraph.

As a learner, making errors in the language process is very common. It involves the making of mistakes and errors. Errors help the learners to establish closer and closer approximations to the system of the target language. The students get problems learning English because there are many differences between Indonesian and English in terms of grammar and vocabulary. 


\section{INFERENCE: Journal of English Language Teaching}

Vol. 3, No. 1, April - July 2020

p-ISSN: 2615-8671

e-ISSN: 2615-868X

Hence (as cited in Monika, 2015: 123) mentions that error analysis is essential for second language teaching and learning. It provides a lot of helpful information about the learner's knowledge of the target language. According to Corder (1981), errors are divided into four categories: omission of some required element, addition of some necessary or incorrect element, selection of an incorrect element, and miss-ordering of element.

Grammar is one of the most crucial of English to communicates with others. When we communicate in written and spoken ways, we should have a good vocabulary and correct grammar with other people. Without grammar, it is hard for people to understand what we say or write. A man who can talk is not guaranteed to has the ability to compose a well-written paragraph. Nevertheless, a man who can write has the ability to speak. Grammar makes a string of words or utterances meaningful. As known, grammar is the set of rules that explain how words are used in language.

Azar (2000: 2) says, "the Simple Present Tense expresses events, perceptions, feelings, or states that occur or always exist, usually, habitually; they exist now, have existed in the past, and probably will exist in the future." Concerning understanding simple present tense, the students have to know of present verb and adjective, the function of verb and adjective, verb and adjective in the present tense. Present tense can be written in affirmative, negative, and interrogative forms. Mary (2000: 294) stated that "adjective is the words which are used to modify nouns or pronoun are usually referred to as adjective." Meanwhile, the first-year students at senior high school are taught some types of English text. Each text is different in its social functions, generic structures, and significant grammatical features that the students should master. Wyrick (2000: 227) stated the writer's description creates a word picture of persons, places, objects, and emotions using a careful selection of detail to make an impression on the reader. It can be concluded that descriptive writing is a kind of writing that consists of description, characteristics, definitions of something, object, or person.

Other errors found in the learner's English descriptive text will also be discussed in this paper. Sometimes learner makes errors in composition such as error of omission (penghilangan kata), error of selection (pemakaian kata yang tidak seharusnya), error of ordering (elemen yang sudah benar tetapi urutannya salah), error of addition (penambahan kata). The researcher is interested in analyzing the use of Simple Present Tense Verb and Adjectives in writing a personal descriptive essay among the students of Private Senior High Schools in Tangerang. The writer chooses descriptive text writing because it paints a colorful piece of a person, place, thing, or idea using concrete and vivid details. Based on the background above, the writer wants to research "The Use of Simple Present Tense Verb and Adjectives in Descriptive Text."

\section{Method}

The research used descriptive analysis and applied case study. The case study is one of several ways of doing social science research. According to Robert (1994:31), the process of descriptive analysis has fifth steps. First, the researcher observed the process of teaching and learning in the classroom. Second, the researcher collected the students writing that they had done in the classroom. Third, the researcher analyzed and classified the simple present tense verb and adjectives of descriptive text. Fourth, the researcher interpreted the data about the kind of errors. The last, the researcher knew the factor of influencing simple present tense verbs and adjectives of writing descriptive text. Fraenkel and Wallen, Marczyk et al. (2005: 18) defined population as all individuals of interest to the researcher. In qualitative research, the sample is intentionally selected according to the study's needs, commonly referred to as 'purposive sampling' or 'purposeful selection.'

For the purpose of a manageable data source, the researcher decided to take only 30 students as the sample of the research who wrote descriptive text about "My Family member" using simple present tense verbs and adjectives consisting of one paragraph.

The researcher used the testing technique as a secondary resource because the material is not given directly to the learner in collecting the data. However, the English teacher gave the material to the learners - the data collected from the written test, which is about the descriptive text. First, the researcher asked the learners to make a descriptive text and checked the errors found in it. Then she took some conclusions about the errors found in the learners' English descriptive text. The main steps in analyzing the data are as follows. 
1. Preparing the topic related to writing.

The researcher decided on the topic which is appropriated to the class lesson. First, she consulted this with the teacher.

2. Asking the learners to write an English descriptive text.

The researcher asked the students to write descriptive text in English.

3. Identifying the errors.

The researcher checked and corrected that are made by the students. She read the writing carefully, marks each error, and makes a correction to it.

4. Taking the conclusion about the errors found in the students' English descriptive texts.

5. Presenting the description of the errors

The errors are classified. In classifying the errors, the researcher used surface strategy taxonomy related to simple present tense verbs and adjectives. The data presented include examples of the errors taken from data as a sample of each category of errors.

The researcher used descriptive analysis technique called percentage (\%), with a percentage from the frequency of information and divided with the number of cases. It was described in the table percentage, and the formula is as below:

$$
\text { Notes: } \begin{aligned}
\mathrm{P}=\frac{F}{N} \times 100 \% \\
\mathrm{~F}=\text { Frequency of student's error } \\
\mathrm{N}=\text { Sum of student's error }
\end{aligned}
$$

\section{Results and Discussion}

The researcher limits the problem by classifying errors related to the Simple Present Tense structure based on the error in the $\mathrm{S}+\mathrm{V}+\mathrm{s}$ /es pattern and Adjective. So, the researcher will not discuss errors that are not related to the focus. Here are several descriptive text writing from the participants as presented below:

\section{S1 Descriptive Text}

$H i$, my name is Davina and I'm originally from Indonesia, but my family moved to Tangerang with me. Mrs. Istiyani is my mom. She is 39 years old. Every morning my mom make breakfast for my family. My mom likes a clean house. Her hobby is

\section{Analysis} cooking. My mom is very beautyful, short hair, short body, she is kinel.

\section{Simple present verb}

There is an error omission of verb inflection-s in the sentence "Every morning my mom makes breakfast for my family." The verb of make should be 'makes.' In this text, the total number of errors is one omission.

\section{Adjective}

There are found error selection of adjective in the sentence "My mom is very beautyful." The word of beautyful should be beautiful. The other error selection in the sentence "she is kinel." The word of kinel should be kind. In this text, the total number of errors are two selections.

\section{S2 Descriptive Text}

My sister's name is Yohana Putri, she is a student in senior high school. Her hobbies is swimming and badminton. She hasa goal is a doctor because the doctor can help people. My sister activity is helping her family at home. She like playing after helping her family. She has the body so beautifuly, tall, and clean. My sister doesn't do the things. 
INFERENCE: Journal of English Language Teaching

Vol. 3, No. 1, April - July 2020

p-ISSN: 2615-8671

e-ISSN: 2615-868X

\section{Analysis}

Simple present verb

There are found error selection of verb in the sentence "Her hobbies is swimming and badminton." The word of hobby is should be hobbies are. Omission of verb inflection -s in the sentence of "She like playing after helping her family." The word like should be 'likes.' In this text, the total number of errors is one selection and one omission.

\section{Adjective}

There is found error selection of adjectives in the sentence "She has the body so beautifuly." The adjective of beautyful should be beautiful. In this text, the total number of errors is one selection.

\section{S3 Descriptive Text}

She is my aunt. Her daily activity is work, meeting with her client. She like reading a book, hang out with her best friend. She doesn't like lazy people. Her hobby is reading and hangout. She has a goal. She want to be a succes woman. Bad habit of her is angry, but I know she is kind. My aunt is beautiful, kind, royal. She has white skin, tall bodies like me and my family. She has one daughter. My aunt has short hair

\section{Analysis} and a body slim.

\section{Simple present verb}

Omission of verb inflection -s in the sentence of "She like reading a book, hang out with her best friend." The verb like should be 'likes.' The verb's selection in the sentence "Her hobby is reading and hangout." The word of hobby is should be hobbies are. Omission of verb inflection -s in the sentence of "She want to be a succes woman". The verb want should be 'wants.' In this text, the total number of errors is one selection and two omissions.

\section{Adjective}

There is found error selection of word in the sentence "She want to be a succes woman." The word of succes should be successful. Misordering in the sentence "My aunt has short hair and a body slim." The word body slim should be 'slim body.' In this text, the total number of errors is one selection and one misordering.

\section{S4 Descriptive Text}

Her name is Megawahyu Lestari. She is my big sister. She is ninteen years old. I and my sister have different character. Her character is bad. She always angry if joke with her, but when she joke with me, I never angry. She always annoy me. She is very child and egoist. But her physical appearance looks great. She is very beautiful but she small. I don't know about my sister hobbies, her goals, her like and dislike or anything about her but I always love my sister.

\section{Analysis}

\section{Simple present verb}

Omission of verb inflection-s in the sentence of "she joke with me." The verb joke should be jokes. Omission of verb inflection-s in the sentence of "She always annoy me." The verb annoy should be 'annoys.' In this text, the total number of errors are two omissions.

\section{Adjective}

There is found error selection of adjectives in the sentence "She is very child and egoist." The adjective of child and egoist should be childish and selfish. In this text, the total number of errors are two selections.

\section{S5 Descriptive Text}

My father is a good model in my family. He is an entrepreneur in car transportation. Every day he controlling the transportation, sell and buy a car. He like to play a game and my father does not like ice drink. My father always tell me and my family the good things. He like give to any people. My father is very kind. My father hobbies 
are playing games, cards, and chess. My father's goal is to success and bad habit is smoking. The character is smart speaking.

\section{Analysis}

\section{Simple present verb}

Omission of verb inflection-s in the sentence of "He like to play a game." The verb like should be 'likes.' Omission of verb inflection -s in the sentence "My father always tell me." The verb tell should be 'tells.' Omission of verb inflection -s in the sentence "He like give to any people." The verb like should be 'likes.' In this text, the number of errors are three omissions.

\section{Adjective}

There is found error selection in the sentence "The character is smart speaking." The word smart speaking should be good at talking. In this text, the total number of errors is one selection.

Table 1

The Total \& Percentage of Simple Present Verb and Adjectives

\begin{tabular}{|l|c|c|c|c|c|c|c|c|}
\hline \multirow{2}{*}{ Categories } & \multicolumn{9}{|c|}{ Types of Errors } \\
\cline { 2 - 10 } & \multicolumn{2}{|c|}{ Omission } & \multicolumn{2}{|c|}{ Addition } & \multicolumn{2}{c|}{ Selection } & \multicolumn{2}{c|}{ Misordering } \\
\cline { 2 - 10 } & Total & $\%$ & Total & $\%$ & Total & $\%$ & Total & $\%$ \\
\hline $\begin{array}{l}\text { Simple Present } \\
\text { Tense Verb }\end{array}$ & 62 & $65,26 \%$ & 5 & $5,26 \%$ & 27 & $28,42 \%$ & 1 & $1,05 \%$ \\
\hline Adjectives & 6 & $13,95 \%$ & 0 & 0 & 33 & $76,74 \%$ & 4 & $9,30 \%$ \\
\hline
\end{tabular}

From Table 1, it can be seen the grammatical error of Using Simple Present Verb and Adjectives in Writing Descriptive Text shown the highest is on the error of Omission, and the lowest is Addition. Diagram 1 below clarifies the frequency of types of errors.



Diagram 1. Frequencies of errors in Simple Present Verb Usage

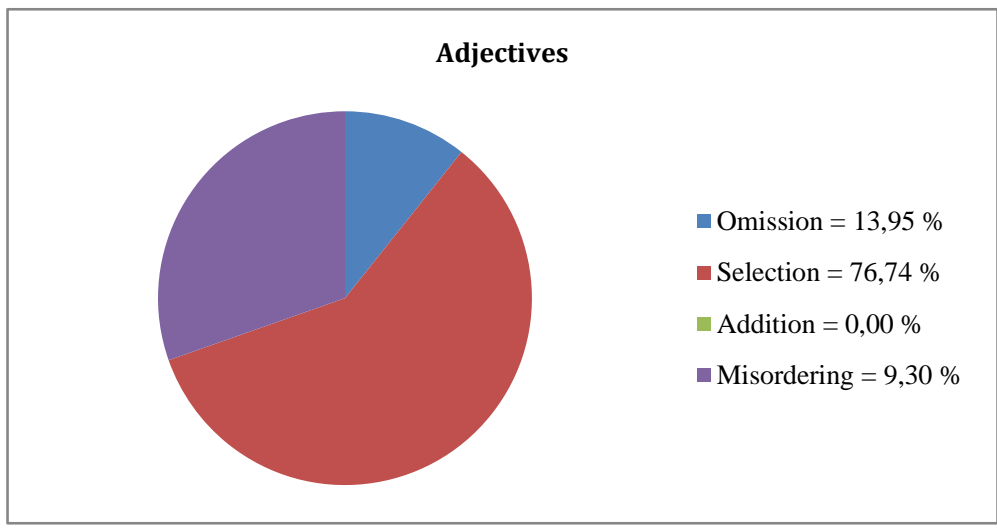

Diagram 2. Frequencies of errors in Adjectives Usage 
INFERENCE: Journal of English Language Teaching

Vol. 3, No. 1, April - July 2020

p-ISSN: 2615-8671

e-ISSN: 2615-868X

The 30 students participated in this research from SMA Islamic Centre and SMA Nusantara 1

Kota Tangerang. The result of the data can be seen in Table 1. Therefore, the simple present verb and adjectives error occurs in the student's writing descriptive text sentence as grouped into four types: Omission, Addition, Selection, and Misordering.

For the grammatical error in writing descriptive text, the researcher divided it into two analyses. There are errors of simple present verb and error of adjective. The researcher found some students made errors in using the simple present verb in the text. There were 62 errors or $65,26 \%$, which the highest frequency error of omission inflection-s verb and inflection-be. The second place is the error of selecting the wrong phoneme, morpheme, structure, or vocabulary item consisting of 27 errors or $28,42 \%$. The error of addition omit elements they regard as redundant but also add redundant elements consisting of 5 errors or $5,26 \%$. The last is the misordering error which consists of 1 error or $1,05 \%$.

Furthermore, the analysis of grammatical error of using adjectives in writing descriptive text. The researcher found the total errors are 43 . There were 33 errors or $76,74 \%$, which the highest frequency of error of selection. In the second place is the error of omission, which consists of six errors or $13,95 \%$. The error of misordering, which consist of 4 errors or 9,30\%. In contrast, there are no errors for addition.

Moreover, most of the students make errors in simple present verb and adjective because of interlingual error, they use mother language and not use an English formation well. They could not describe and distinguish simple present tense to add -s or -es, use the correct tenses, and lack vocabulary. The most errors students usually make in adjectives is the selection of words. They got difficulties choosing and complete the word. The other factor is an intralingual error such as inappropriate grammar teaching method by the teacher.

\section{Conclusions}

This study shows that the tenth-grade students of SMA Islamic Centre and SMA Nusantara 1 Kota Tangerang in the academic year 2019/2020 made many errors in their writing descriptive texts. The analysis results show that the thirty students' compositional works produce 138 errors divided into two categories: simple present verb and adjectives. Below are conclusions that need to be taken as the answer to the formulation of the problems:

Based on the findings of the analysis, the researcher classified the errors in using simple present verb percentage: omission $(65,26 \%)$, addition $(5,26 \%)$, selection $(28,42 \%)$, misordering $(1,05 \%)$. The first dominant error is the omission in using the simple present tense, it means that the students were not able to put "s" or "es" in the verb if the pronoun is a third singular person. The errors of using adjective percentage: omission $(13,95 \%)$, addition $(0 \%)$, selection $(76,34 \%)$, misordering $(9,30 \%)$. In using adjectives, the dominant error is selection, which means that the students were challenged to pay attention to choose and complete the word. The last one is the cause of errors, simple present tense, and adjectives in writing descriptive text made by students are interlingual and intralingual errors. They use their mother tongues and do not use an English formation well. They could not describe and distinguish the tenses, lack vocabulary, choose, and complete the word. The intralingual factor is the inappropriate grammar teaching method by the teacher.

As explained by the researcher above, this research concludes that the students could not describe and distinguish the tenses, choose, and complete the words in writing descriptive text. Students have to learn the material of simple present verb and adjective again from their English teacher to understand using simple present verb and adjective in writing any text, especially in descriptive text.

\section{References}

Ansell, M. (2000). Free English Grammar. SeyfiHoca: www.seyfihoca.com

Azzar, B. S. (2000). Understanding and Using English Grammar. New York: Longman.

Ciesielkiewicz, M. \& Márquez, E. (2015). Error Analysis and Its Relevance to Teaching ESL Composition, International Journal of Linguistics, (www.macrothink.org/ijl 119)

Corder, S. P., (1981). Error Analysis and Interlanguage, Oxford: Oxford University Press.

Fraenkel, R., Jack, W, Norman, E. \& Hyun, H. H. (2012). How to Design and Evaluate Research in Education. New York: McGraw-Hill 
INFERENCE: Journal of English Language Teaching

Vol. 3, No. 1, April - July 2020

p-ISSN: 2615-8671

e-ISSN: $2615-868 \mathrm{X}$

Wyrick, J. (2000). Steps to Writing Well. New York. Cengage Learning.

Yin, R. (1994). Designing Case Studies, "Case Study Research: Design \& Methods (2 ${ }^{\text {nd }}$ ed.), Thousand Oaks, CA: Sage Publications. 